\title{
FAKTOR RISIKO KEJADIAN STUNTING PADA BALITA USIA 24 - 36 BULAN DI KECAMATAN SEMARANG TIMUR
}

\author{
Roudhotun Nasikhah, Ani Margawati*) \\ Program Studi Ilmu Gizi Fakultas Kedokteran Universitas Diponegoro \\ Jl.Dr.Sutomo No.14, Semarang, Telp (024) 8453708, Email : gizifk@undip.ac.id
}

\begin{abstract}
Background: Stunting is a linear growth disorders that showed by z score height for age < -2 SD. Prevalence of stunting in Semarang reached 20,66\% with highest incident in East Semarang District (40,16\%) and at aged 24 36 month. Study about risk factor of stunting related socioeconomic factor, parental body height, history of morbidity during pregnancy and history of infection in children should be needed. The purpose of this study was to analyze the risk factors of stunting among children aged $24-36$ month.

Methods : An observasional study with case control design on children aged 24 - 36 month at East Semarang District. The samples were selected by consecutive sampling with number of samples were 31 subject for each groups. Stunting were assesed by z-score height for age which analyzed by WHO Anthro 2005. Social economic data, history of morbidity during pregnancy and history of acute diarrhea, history of acute upper respiratory tract infection were measured using questionaires and KIA. Birth weights were determined from KMS and parent's height were measured using microtoise. Bivariate analyzed with Chi Square or Fisher Exact test and multivariate analysis with multiple logistic regression.

Result : Prevalence of stunted children in this study is 34,45\%, which 64,5\% of them were girls. The multivariate analysis showed that risk factor of stunting in children aged $24-36$ month were having mother's height $<150 \mathrm{~cm}$ $(p=0,006 ; O R=10,3)$, father's height $<162 \mathrm{~cm}(p=0,013 ; O R=7,4)$, low paternal education $(p=0,033 ; O R=5,6)$, and low family income $(p=0,017 ; O R=7,2)$. Meanwhile birth weight, history of morbidity during pregnancy, history of acute diarrhea, history of acute upper respiratory tract infection, maternal education, mother's knowledge about nutrition and number of household were not proven as the risk factor of stunting in children.

Conclusion: Short parental body height, low paternal education and low family income are the risk factor of stunting among children aged $24-36$ month.
\end{abstract}

Keywords : Stunting; malnutrition; children; risk factor; socioeconomic

\section{ABSTRAK}

Latar Belakang : Stunting merupakan gangguan pertumbuhan linier yang ditunjukan dengan nilai z skore TB/U kurang dari -2 SD. Prevalensi stunting di Semarang mencapai 20,66\% dengan kejadian tertinggi di Semarang Timur (40,16\%) dan pada usia 24 - 36 bulan. Penelitian tentang faktor risiko kejadian stunting pada balita terkait dengan faktor sosial ekonomi, tinggi badan orang tua, risiko penyakit kehamilan dan riwayat infeksi sangat diperlukan. Tujuan dari penelitian ini adalah untuk menganalisis faktor risiko stunting pada balita usia 24 - 36 bulan.

Metode : Penelitian observasional dengan desain case control pada balita usia 24 - 36 bulan yang berada di Semarang Timur. Teknik pengambilan sampel dilakukan dengan cara consecutive sampling dengan jumlah sampel 31 subyek pada setiap kelompok. Stunting diukur berdasarkan z-score tinggi badan menurut umur (TB/U) dianalisis dengan software World Health Organization (WHO) Anthro 2005. Data sosial ekonomi, riwayat penyakit kehamilan, riwayat diare akut dan riwayat infeksi pernafasan atas akut diukur menggunakan kuesioner dan buku KIA. Data berat badan lahir dikumpulkan berdasarkan KMS serta tinggi badan orang tua diukur dengan microtoise. Analisis bivariat menggunakan uji Chi Square dan Fisher Exact dan analisis multivariat menggunakan uji regresi logistik ganda.

Hasil : Pada penelitian ini terdapat 34,45\% balita stunting dimana 64,5\% berjenis kelamin perempuan. Hasil analisis multivariat menunjukkan bahwa faktor risiko kejadian stunting pada balita usia 24 - 36 bulan antara lain tinggi badan ibu $<150 \mathrm{~cm}(p=0,006 ; O R=10,3)$, tinggi badan ayah $<162 \mathrm{~cm}(p=0,013 ;$ OR=7,4), pendidikan ayah rendah $(p=0,033 ; O R=5,6)$ dan pendapatan perkapita yang rendah $(p=0,017 ; O R=7,2)$. Sedangkan berat badan lahir, riwayat penyakit kehamilan, riwayat diare akut, riwayat penyakit infeksi saluran pernafasan atas akut, pendidikan ibu, pengetahuan gizi ibu dan jumlah anggota dalam rumah tangga tidak terbukti sebagai faktor risiko kejadian stunting pada balita.

Kesimpulan : Tinggi badan orang tua yang pendek, pendidikan ayah yang rendah dan pendapatan perkapita yang rendah merupakan faktor risiko yang berpengaruh terhadap kejadian stunting pada balita usia 24 - 36 bulan.

${ }^{*}$ Penulis Penanggungjawab 
Kata Kunci : stunting; malnutrisi; balita; faktor risiko; sosial ekonomi

\section{PENDAHULUAN}

Stunting merupakan gangguan pertumbuhan linier yang disebabkan adanya malnutrisi asupan zat gizi kronis dan atau penyakit infeksi kronis maupun berulang yang ditunjukkan dengan nilai zscore tinggi badan menurut usia (TB/U) kurang dari -2 standar deviasi (SD) berdasarkan standar World Health Organization (WHO). ${ }^{1}$ Berdasarkan data Riset Kesehatan Dasar (Riskesdas) 2010 diketahui bahwa prevalensi balita stunting di Indonesia mencapai 35,6\% dengan kejadian yang tinggi pada balita usia 24 - 36 bulan $(41,4 \%)$. Prevalensi stunting tersebut lebih tinggi dibandingkan angka prevalensi gizi kurang dan buruk (17,9\%), balita kurus $(13,3 \%)$ serta balita gemuk (14\%). ${ }^{2}$ Kondisi stunting pada masa balita dapat menyebabkan gangguan perkembangan fungsi kognitif dan psikomotor serta penurunan produktivitas ketika dewasa. ${ }^{3}$ Beberapa faktor yang diduga berhubungan dengan kejadian stunting pada balita antara lain berat badan lahir balita, riwayat infeksi balita, riwayat penyakit kehamilan, tinggi badan orangtua dan faktor sosial ekonomi. ${ }^{4,5,6,7}$

Kondisi kesehatan dan status gizi ibu selama hamil dapat mempengaruhi pertumbuhan dan perkembangan janin. Ibu yang mengalami kekurangan energi kronis atau anemia selama kehamilan akan melahirkan bayi dengan berat lahir rendah (BBLR). ${ }^{4}$ Berat badan lahir rendah banyak dihubungkan dengan tinggi badan yang kurang atau stunting pada balita. ${ }^{5}$ Tinggi badan orang tua juga berkaitan dengan kejadian stunting. Ibu yang pendek memiliki kemungkinan melahirkan bayi yang pendek pula. Hasil penelitian di Egypt menunjukkan bahwa anak yang lahir dari ibu yang tinggi badan $<150 \mathrm{~cm}$ memiliki risiko lebih tinggi untuk tumbuh menjadi stunting. ${ }^{6}$ Faktor lain yang berhubungan dengan stunting adalah kejadian infeksi seperti diare dan infeksi saluran pernafasan. Penelitian di Peru membuktikan bahwa kejadian diare dapat menyebabkan efek jangka panjang berupa defisit pertumbuhan tinggi badan. ${ }^{7}$

Faktor sosial ekonomi meliputi pendapatan perkapita, pendidikan orangtua, pengetahuan ibu tentang gizi dan jumlah anggota dalam rumah tangga secara tidak langsung juga berhubungan dengan kejadian stunting. Pendapatan akan mempengaruhi pemenuhan zat gizi keluarga dan kesempatan dalam mengikuti pendidikan formal. Rendahnya pendidikan disertai rendahnya pengetahuan gizi sering dihubungkan dengan kejadian malnutrisi. ${ }^{8}$
Prevalensi stunting di Jawa Tengah mencapai 33,9\%. ${ }^{2}$ Tahun 2011 prevalensi stunting pada balita di Semarang sebesar 20,66\% dengan kejadian tertinggi di Kecamatan Semarang Timur $(40,16 \%) .^{9}$ Dari hasil pengukuran tinggi badan yang dilakukan pada 238 balita di tiga kelurahan di Kecamatan Semarang Timur, ditemukan 82 balita stunting (pendek). Berdasarkan uraian di atas, peneliti tertarik untuk mengetahui faktor risiko kejadian stunting pada balita usia $24-36$ bulan di Kecamatan Semarang Timur. Tujuan dari penelitian ini adalah untuk menganalisis faktor risiko kejadian stunting pada balita usia 24 - 36 bulan.

\section{METODE PENELITIAN}

Penelitian ini dilaksanakan di Kecamatan Semarang Timur meliputi Kelurahan Mlatiharjo, Bugangan dan Kebon Agung pada bulan Juni-Juli 2012. Jenis penelitian observasional dengan rancangan penelitian case control. Populasi dalam penelitian ini adalah seluruh balita usia $24-36$ bulan yang berada di Kota Madya Semarang. Subyek dalam penelitian adalah semua kasus dan kontrol yang dipilih dengan perbandingan kasus dan kontrol 1:1. Kasus adalah balita stunting usia 24 - 36 bulan dengan indeks z-score TB/U <-2 SD dan kontrol adalah balita usia $24-36$ bulan dengan indeks z-score TB/U -2 SD sampai +2SD. Responden dalam penelitian ini adalah ibu balita yang terpilih menjadi subyek penelitian. Kriteria inklusi dalam penelitian ini adalah balita usia $24-$ 36 bulan yang tinggal menetap di Kecamatan Semarang Timur, hidup bersama kedua orangtua dan memiliki Kartu Menuju Sehat (KMS) serta buku Kesehatan Ibu dan Anak (KIA). Jumlah sampel yang digunakan sebanyak 31 subyek pada masing-masing kelompok yang dihitung menggunakan rumus kasus kontrol dan telah ditambah dengan kemungkinan drop out (10\%). Pengambilan subyek dilakukan secara consecutive sampling dan dilakukan matching terhadap kelompok jenis kelamin.

Variabel terikat adalah status gizi stunting balita, sedangkan variabel bebas terdiri dari berat badan lahir balita, riwayat diare akut, riwayat penyakit infeksi saluran pernafasan atas akut, riwayat penyakit kehamilan ibu, tinggi badan orang tua dan faktor sosial ekonomi meliputi pendapatan perkapita, pendidikan orangtua, jumlah anggota dalam rumah tangga dan pengetahuan ibu tentang gizi. Data yang dikumpulkan antara lain 
karakteristik subyek, berat badan lahir balita, riwayat infeksi balita, riwayat penyakit kehamilan ibu, faktor sosial ekonomi dan data antropometri. Instrumen yang digunakan adalah kuesioner.

Berat badan lahir adalah berat badan bayi ketika lahir atau paling lambat sampai bayi berumur 1 hari dilihat dari KMS dimana bila berat badan lahir kurang dari 2500 gram berarti berat badan lahir rendah dan bila lebih dari atau sama dengan 2500 gram berarti normal. ${ }^{5}$ Riwayat diare balita adalah ada tidaknya diare yang berlangsung $\leq 2$ minggu yang terjadi setiap bulan berturut-turut dalam tiga bulan terakhir. Riwayat infeksi saluran pernafasan atas adalah ada tidaknya gejala batuk yang disertai demam, flu atau sesak nafas yang berlangsung $\leq 2$ minggu terjadi setiap bulan berturut-turut dalam tiga bulan terakhir. Riwayat penyakit kehamilan adalah ada tidaknya penyakit yang diderita ibu selama kehamilan seperti infeksi TORCH (toxoplasma, rubella, cytomegalovirus, herpes simplex), malaria, preeklampsia-eklampsia, hiperemesis atau gejala anemia diperoleh melalui wawancara dan buku KIA atau catatan pemeriksaan kehamilan. Tinggi badan orang tua adalah ukuran tubuh linier ayah dan ibu yang diukur menggunakan microtoise dengan ketelitian $0,1 \mathrm{~cm}$ dari ujung kaki sampai kepala dengan kategori ibu pendek bila tinggi badan $<150 \mathrm{~cm}$ dan normal bila $\geq 150 \mathrm{~cm}^{6}$, sedangkan ayah pendek bila tinggi badan $<162 \mathrm{~cm}$ dan normal bila $\geq 162$ $\mathrm{cm}$.

Pendapatan perkapita yaitu jumlah pengeluaran pangan dan non pangan keluarga selama sebulan menggunakan formulir pengeluaran yang dinyatakan dalam rupiah perbulan perkapita dengan kategori rendah bila $\leq$ Rp. 234.799 dan cukup bila > Rp. 234.799. ${ }^{10}$ Pendidikan orangtua adalah jenjang pendidikan formal terakhir yang ditamatkan ibu dan ayah berdasarkan kepemilikan ijazah dengan kategori rendah bila pendidikan kurang dari atau sama dengan sekolah menengah pertama dan tinggi bila lebih dari sekolah menengah pertama. Pengetahuan ibu tentang gizi adalah kemampuan ibu dalam menjawab pertanyaan mengenai gizi menggunakan kuesioner sebanyak 20 pertanyaan, dengan ketentuan nilai 0 bila jawaban salah, nilai 1 bila jawaban benar kemudian dilakukan penjumlahan skor dibagi jumlah pertanyaan dikali $100 \%$. Responden dikatakan pengetahuan kurang bila jawaban benar $<70 \%$ dan pengetahuan baik bila jawaban benar $\geq 70 \%$. $^{11}$ Jumlah anggota keluarga adalah banyaknya anggota keluarga yang hidup bersama dalam satu atap, satu penghasilan dan makan dalam satu dapur.

Analisis data menggunakan program SPSS. Analisis univariat untuk mengetahui distribusi frekuensi dari variabel yang diteliti. Analisis bivariat menggunakan uji Chi square dengan $\alpha$ 0,05 . Jika pada tabel memiliki expected value kurang dari 5 lebih dari 20\% digunakan uji Fisher Exact. Analisis multivariat menggunakan uji Regresi Logistik Ganda.

\section{HASIL PENELITIAN}

\section{Karakteristik Subyek dan Responden}

Jumlah subyek dalam penelitian ini adalah 62 balita yang terdiri dari 31 kasus dan 31 kontrol. Hasil penelitian menunjukkan bahwa sebagian besar subyek berjenis kelamin perempuan $(64,5 \%)$ dengan nilai median z-skore tinggi badan menurut umur adalah -1,91 SD dimana nilai z-skor terendah $-4,03$ SD dan nilai $\mathrm{z}$ skor tertinggi 0,99 SD. Karakteristik responden yang dimaksud adalah pekerjaan ibu. Hasil penelitian menunjukkan ibu yang tidak bekerja pada kelompok kasus $(58,1 \%)$ lebih tinggi daripada kelompok kontrol $(45,2 \%)$. Pekerjaan ibu pada kelompok kasus 22,6\% sebagai pedagang, lainnya buruh atau cleaning service.

\section{Berat badan lahir dan riwayat penyakit infeksi balita}

Hasil penelitian menunjukkan sebagian subyek baik kelompok kasus maupun kelompok kontrol memiliki berat badan lahir yang normal. Nilai median berat badan lahir pada kelompok kasus adalah 3000 gram dengan nilai minimum 2300 gram dan nilai maksimum 3900 gram. Tabel 1 menunjukkan $22,6 \%$ subyek pada kelompok kasus mengalami diare dan sebagian besar subyek pada kelompok kasus maupun kontrol memiliki riwayat kejadian infeksi saluran pernafasan atas.

\section{Riwayat penyakit kehamilan dan tinggi badan orang tua}

Hasil penelitian menunjukkan 29\% ibu dari kelompok kasus memiliki riwayat penyakit kehamilan. Hasil penelitian juga menunjukkan pada kelompok kasus, rerata \pm SD tinggi badan ibu adalah $150,7 \pm 4,46$ sedangkan rerata \pm SD tinggi badan ayah adalah $163,8 \pm 7,04$. Ibu maupun ayah pendek lebih banyak ditemukan pada kelompok kasus daripada kelompok kontrol. 
Tabel 1. Distribusi frekuensi jenis kelamin subyek,berat badan lahir, riwayat penyakit infeksi balita, riwayat penyakit kehamilan ibu, tinggi badan orang tua dan faktor sosial ekonomi.

\begin{tabular}{|c|c|c|c|c|}
\hline & \multicolumn{2}{|r|}{ Kasus } & \multicolumn{2}{|c|}{ Kontrol } \\
\hline & $\mathrm{N}$ & $\%$ & $\mathrm{~N}$ & $\%$ \\
\hline \multicolumn{5}{|l|}{ 1. Jenis Kelamin } \\
\hline - Laki-laki & 11 & $35,5 \%$ & 11 & $35,5 \%$ \\
\hline - Perempuan & 20 & $64,5 \%$ & 20 & $64,5 \%$ \\
\hline \multicolumn{5}{|l|}{ 2. Berat badan lahir } \\
\hline$-\quad<2500$ gram & 2 & $6,5 \%$ & 3 & $9,7 \%$ \\
\hline - $\quad \geq 2500$ gram & 29 & $93,5 \%$ & 28 & $90,3 \%$ \\
\hline \multicolumn{5}{|l|}{ 3. Riwayat Diare } \\
\hline - Ada & 7 & $22,6 \%$ & 0 & $0 \%$ \\
\hline - $\quad$ Tidak & 24 & $77,4 \%$ & 31 & $100,0 \%$ \\
\hline \multicolumn{5}{|l|}{ 4. Riwayat infeksi pernafasan akut } \\
\hline - Ada & 21 & $67,7 \%$ & 17 & $54,8 \%$ \\
\hline - $\quad$ Tidak & 10 & $32,3 \%$ & 14 & $45,2 \%$ \\
\hline \multicolumn{5}{|l|}{ 5. Riwayat penyakit kehamilan } \\
\hline - Ada & 9 & $29,0 \%$ & 7 & $22,6 \%$ \\
\hline - Tidak & 22 & $71,0 \%$ & 24 & $77,4 \%$ \\
\hline \multicolumn{5}{|l|}{ 6. Tinggi badan ibu } \\
\hline$-\quad<150 \mathrm{~cm}$ & 18 & $58,1 \%$ & 9 & $29,0 \%$ \\
\hline$-\quad \geq 150 \mathrm{~cm}$ & 13 & $41,9 \%$ & 22 & $71,0 \%$ \\
\hline \multicolumn{5}{|l|}{ 7. Tinggi badan ayah } \\
\hline$-\quad<162 \mathrm{~cm}$ & 15 & $48,4 \%$ & 7 & $22,6 \%$ \\
\hline$-\quad \geq 162 \mathrm{~cm}$ & 16 & $51,6 \%$ & 24 & $77,4 \%$ \\
\hline \multicolumn{5}{|l|}{ 8. Pendidikan ibu } \\
\hline - Tidak tamat SD & - & - & 1 & $3,2 \%$ \\
\hline$-\quad$ SD & 3 & $9,7 \%$ & 2 & $6,5 \%$ \\
\hline - $\quad$ SMP & 8 & $25,8 \%$ & 3 & $9,7 \%$ \\
\hline - $\quad$ SMA/SMK & 17 & $54,8 \%$ & 20 & $64,5 \%$ \\
\hline - $\quad$ Diploma/Perguruan tinggi & 3 & $9,7 \%$ & 5 & $16,1 \%$ \\
\hline \multicolumn{5}{|l|}{ 9. Pendidikan ayah } \\
\hline - Tidak Tamat SD & 1 & $3,2 \%$ & - & \\
\hline$-\quad$ SD & 5 & $16,1 \%$ & 1 & $3,2 \%$ \\
\hline - $\quad$ SMP & 8 & $25,8 \%$ & 4 & $12,9 \%$ \\
\hline - $\quad$ SMA/SMK & 15 & $48,4 \%$ & 19 & $61,3 \%$ \\
\hline - Diploma/Perguruan Tinggi & 2 & $6,5 \%$ & 7 & $22,6 \%$ \\
\hline \multicolumn{5}{|l|}{ 10. Pengetahuan ibu tentang Gizi } \\
\hline - $\quad$ Kurang $(<70 \%)$ & 18 & $58,1 \%$ & 10 & $32,3 \%$ \\
\hline$-\quad$ Baik $(\geq 70 \%)$ & 13 & $41,9 \%$ & 21 & $67,7 \%$ \\
\hline \multicolumn{5}{|l|}{ 11. Pendapatan perkapita } \\
\hline - $\quad$ Rendah ( $\leq$ Rp. 234.799) & 15 & $48,4 \%$ & 6 & $19,4 \%$ \\
\hline - $\quad$ Cukup(>Rp. 234.799) & 16 & $51,6 \%$ & 25 & $80,6 \%$ \\
\hline \multicolumn{5}{|l|}{ 12. Jumlah anggota rumah tangga } \\
\hline - $\quad$ Kecil $<6$ orang & 20 & $64,5 \%$ & 19 & $61,3 \%$ \\
\hline - $\quad$ Besar $\geq 6$ orang & 11 & $35,5 \%$ & 12 & $38,7 \%$ \\
\hline
\end{tabular}




\section{Faktor Sosial Ekonomi}

Hasil penelitian menunjukkan pada kelompok kasus memiliki pendapatan perkapita berkisar antara Rp.200.735 - Rp.641.443 dengan nilai median Rp.241.763,89. Tabel 1 juga menunjukkan bahwa pada kedua kelompok, sebagian besar tingkat pendidikan ibu dan ayah adalah pendidikan menengah atas dengan jumlah

anggota dalam rumah tangga yang tergolong kecil ( $<6$ orang). Jumlah ibu pada kelompok kasus yang memiliki pengetahuan tentang gizi yang kurang lebih banyak dibandingkan dengan kelompok kontrol yaitu sebesar $58,1 \%$.

\section{Analisis Bivariat}

Tabel 2. Berat badan lahir, riwayat penyakit infeksi balita, riwayat penyakit kehamilan ibu, tinggi badan orang tua dan faktor sosial ekonomi dengan kejadian stunting

\begin{tabular}{|c|c|c|c|c|c|c|}
\hline \multirow{2}{*}{ Variabel } & \multicolumn{2}{|c|}{ Kasus } & \multicolumn{2}{|c|}{ Kontrol } & \multirow{2}{*}{$\begin{array}{c}\text { OR } \\
(95 \% \mathrm{CI}) \\
\end{array}$} & \multirow[b]{2}{*}{$\mathrm{p}$} \\
\hline & $\mathrm{N}$ & $\%$ & $\mathrm{~N}$ & $\%$ & & \\
\hline 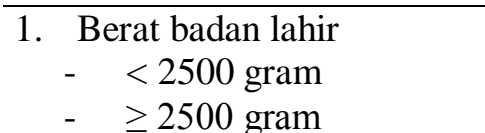 & $\begin{array}{l}2 \\
29\end{array}$ & $\begin{array}{l}6,5 \% \\
93,5 \%\end{array}$ & $\begin{array}{l}3 \\
28\end{array}$ & $\begin{array}{l}9,7 \% \\
90,3 \%\end{array}$ & $\begin{array}{c}0,64 \\
(0,10-4,15)\end{array}$ & $1,000^{\mathrm{a}}$ \\
\hline $\begin{array}{ll}\text { 2. } & \text { Riwayat Diare } \\
\text { - } & \text { Ada } \\
\text { - } & \text { Tidak }\end{array}$ & $\begin{array}{l}7 \\
24\end{array}$ & $\begin{array}{l}22,6 \% \\
77,4 \%\end{array}$ & $\begin{array}{l}0 \\
31\end{array}$ & $\begin{array}{l}0 \% \\
100,0 \\
\%\end{array}$ & $\begin{array}{c}2,29 \\
(1,69-3,09)\end{array}$ & $0,011^{\mathrm{a}, \mathrm{c}}$ \\
\hline $\begin{array}{ll}\text { 3. } & \text { Riwayat ISPA } \\
- & \text { Ada } \\
- & \text { Tidak } \\
\end{array}$ & $\begin{array}{l}21 \\
10 \\
\end{array}$ & $\begin{array}{l}67,7 \% \\
32,3 \% \\
\end{array}$ & $\begin{array}{l}17 \\
14\end{array}$ & $\begin{array}{l}54,8 \% \\
45,2 \% \\
\end{array}$ & $\begin{array}{c}1,73 \\
(0,62-4,86)\end{array}$ & $0,297^{\mathrm{b}}$ \\
\hline $\begin{array}{lll}\text { 4. } & \text { Riwayat } & \text { penyakit } \\
\text { kehamilan } & \\
- & \text { Ada } & \\
- & \text { Tidak } & \\
\end{array}$ & $\begin{array}{l}9 \\
22\end{array}$ & $\begin{array}{l}29,0 \% \\
71,0 \%\end{array}$ & $\begin{array}{l}7 \\
24\end{array}$ & $\begin{array}{l}22,6 \% \\
77,4 \%\end{array}$ & $\begin{array}{c}1,40 \\
(0,45-4,41)\end{array}$ & $0,562^{\mathrm{b}}$ \\
\hline $\begin{array}{ll}\text { 5. } & \text { Tinggi badan ibu } \\
- & <150 \mathrm{~cm} \\
- & \geq 150 \mathrm{~cm} \\
\end{array}$ & $\begin{array}{l}18 \\
13 \\
\end{array}$ & $\begin{array}{l}58,1 \% \\
41,9 \% \\
\end{array}$ & $\begin{array}{l}9 \\
22 \\
\end{array}$ & $\begin{array}{l}29,0 \% \\
71,0 \% \\
\end{array}$ & $\begin{array}{c}3,38 \\
(1,18-9,71)\end{array}$ & $0,021^{b, c}$ \\
\hline $\begin{array}{l}\text { 6. } \quad \text { Tinggi badan ayah } \\
-\quad<162 \mathrm{~cm} \\
-\quad \geq 162 \mathrm{~cm}\end{array}$ & $\begin{array}{l}15 \\
16 \\
\end{array}$ & $\begin{array}{l}48,4 \% \\
51,6 \%\end{array}$ & $\begin{array}{l}7 \\
24\end{array}$ & $\begin{array}{l}22,6 \% \\
77,4 \%\end{array}$ & $\begin{array}{c}3,21 \\
(1,07-9,63)\end{array}$ & $0,034^{\mathrm{b}, \mathrm{c}}$ \\
\hline $\begin{array}{ll}\text { 7. } & \text { Pendidikan ibu } \\
- & \text { Rendah }(\leq \mathrm{SMP}) \\
- & \text { Tinggi }(>\mathrm{SMP})\end{array}$ & $\begin{array}{l}11 \\
20\end{array}$ & $\begin{array}{l}35,5 \% \\
64,5 \%\end{array}$ & $\begin{array}{l}6 \\
25\end{array}$ & $\begin{array}{l}19,4 \% \\
80,6 \%\end{array}$ & $\begin{array}{c}2,29 \\
(0,72-7,28)\end{array}$ & $0,155^{\mathrm{b}}$ \\
\hline $\begin{array}{ll}8 . & \text { Pendidikan ayah } \\
- & \text { Rendah }(\leq \text { SMP) } \\
- & \text { Tinggi }(>\text { SMP })\end{array}$ & $\begin{array}{l}14 \\
17\end{array}$ & $\begin{array}{l}45,2 \% \\
54,8 \%\end{array}$ & $\begin{array}{l}5 \\
26\end{array}$ & $\begin{array}{l}16,1 \% \\
83,9 \%\end{array}$ & $\begin{array}{c}4,28 \\
(1,30-14,04)\end{array}$ & $0,013^{b, c}$ \\
\hline $\begin{array}{cc}\text { 9. } & \text { Pengetahuan gizi ibu } \\
- & \text { Kurang }(<70 \%) \\
- & \text { Baik }(\geq 70 \%) \\
\end{array}$ & $\begin{array}{l}18 \\
13 \\
\end{array}$ & $\begin{array}{l}58,1 \% \\
41,9 \% \\
\end{array}$ & $\begin{array}{l}10 \\
21\end{array}$ & $\begin{array}{l}32,3 \% \\
67,7 \% \\
\end{array}$ & $\begin{array}{c}2,91 \\
(1,03-8,20)\end{array}$ & $0,041^{\mathrm{b}, \mathrm{c}}$ \\
\hline $\begin{array}{l}\text { 10. Pendapatan keluarga } \\
\text { - } \quad \text { Rendah } \\
-\quad \text { Cukup }\end{array}$ & $\begin{array}{l}15 \\
16 \\
\end{array}$ & $\begin{array}{l}48,4 \% \\
51,6 \%\end{array}$ & $\begin{array}{l}6 \\
25\end{array}$ & $\begin{array}{l}19,4 \% \\
80,6 \%\end{array}$ & $\begin{array}{c}3,91 \\
(1,26-12,16)\end{array}$ & $0,016^{\mathrm{b}, \mathrm{c}}$ \\
\hline $\begin{array}{l}\text { 11. Jumlah anggota keluarga } \\
\text { - } \quad \text { Kecil }<6 \text { orang } \\
\text { - } \quad \text { Besar } \geq 6 \text { orang }\end{array}$ & $\begin{array}{l}20 \\
11\end{array}$ & $\begin{array}{l}64,5 \% \\
35,5 \%\end{array}$ & $\begin{array}{l}19 \\
12\end{array}$ & $\begin{array}{l}61,3 \% \\
38,7 \%\end{array}$ & $\begin{array}{c}1,15 \\
(0,41-3,22)\end{array}$ & $0,793^{\mathrm{b}}$ \\
\hline
\end{tabular}

${ }^{a}$ uji Fisher, b uji Chi Square, ${ }^{\mathrm{c}}$ signifikan $\mathrm{p}<0,05$

Tabel 2 menunjukkan bahwa riwayat diare, tinggi badan ibu, tinggi badan ayah, pendidikan ayah, pengetahuan ibu tentang gizi dan pendapatan perkapita adalah faktor risiko kejadian stunting yang bermakna dengan nilai $p$ value < 0,05 ; sedangkan berat badan lahir, riwayat infeksi 
saluran pernafasan atas, riwayat penyakit dalam rumah tangga merupakan faktor risiko kehamilan, pendidikan ibu dan jumlah anggota kejadian stunting yang tidak bermakna.

Tabel 3. Hasil analisis regresi logistik ganda faktor yang paling berpengaruh terhadap stunting

\begin{tabular}{lcccc}
\hline \multicolumn{1}{c}{ Variabel } & Koefisien & $\mathrm{P}$ & OR & $95 \%[\mathrm{CI}]$ \\
\hline Tinggi badan ibu $<150 \mathrm{~cm}$ & 2,333 & 0,006 & 10,31 & $1,93-55,02$ \\
Tinggi badan ayah $<162 \mathrm{~cm}$ & 1,999 & 0,013 & 7,38 & $1,51-35,94$ \\
Pendidikan ayah rendah & 1,721 & 0,033 & 5,59 & $1,15-27,24$ \\
Pendapatan $\leq$ Rp. 234.799 & 1,976 & 0,017 & 7,21 & $1,43-36,44$ \\
Konstanta & $-3,311$ & $<0,001$ & 0,036 & \\
\hline
\end{tabular}

Variabel yang ikut dalam analisis multivariat adalah riwayat diare, tinggi badan ibu, tinggi badan ayah, pendidikan ibu, pendidikan ayah, pengetahuan ibu tentang gizi dan pendapatan perkapita. Hasil analisis menunjukkan terdapat empat faktor risiko yang paling berpengaruh terhadap kejadian stunting yaitu ibu yang pendek, ayah yang pendek, tingkat pendidikan ayah yang rendah dan pendapatan perkapita yang rendah. Diantara keempat variabel tersebut, tinggi badan ibu memiliki pengaruh yang paling besar terhadap kejadian stunting dengan nilai $\mathrm{OR}=10,31$. Berdasarkan tabel 3, dapat diperoleh persamaan untuk memprediksi terjadinya stunting adalah y = 3,311+2,333(tinggi badan ibu)+1,999(tinggi badan ayah)+1,721 (pendidikan ayah)+1,976(pendapatan perkapita). Bila subyek memiliki faktor risiko tersebut maka probabilitas menjadi stunting adalah $99,08 \%$

\section{PEMBAHASAN}

Hasil penelitian ini diketahui prevalensi kejadian stunting pada balita usia 24 - 36 bulan di Kecamatan Semarang Timur sebesar $34,45 \%$. Hasil penelitian ini lebih tinggi daripada hasil Riskesdas 2010 di Jawa Tengah dimana prevalensi stunting sebesar 33,9\%. ${ }^{2}$ Penelitian ini juga menunjukkan stunting banyak dialami oleh balita perempuan $(64,5 \%)$ daripada balita laki-laki $(35,5 \%)$. Hasil penelitian tersebut berbeda dengan penelitian di Maluku yang menunjukkan bahwa laki-laki lebih berisiko mengalami stunting daripada perempuan. ${ }^{12}$ Pada tahun pertama kehidupan, laki-laki lebih rentan mengalami malnutrisi daripada perempuan karena ukuran tubuh laki-laki yang besar dimana membutuhkan asupan energi yang lebih besar pula sehingga bila asupan makan tidak terpenuhi dan kondisi tersebut terjadi dalam jangka waktu lama dapat meningkatkan gangguan pertumbuhan. ${ }^{13}$ Namun pada tahun kedua kehidupan, perempuan lebih berisiko menjadi stunting. Hal ini terkait pola asuh orang tua dalam memberikan makan pada anak dimana dalam kondisi lingkungan dan gizi yang baik, pola pertumbuhan anak laki-laki lebih baik daripada perempuan. Di Filipina, laki-laki lebih dulu dikenalkan makanan pendamping dimana makanan yang diberikan kaya akan protein yang penting dalam proses pertumbuhan, sedangkan perempuan lebih banyak diberikan sayuran. ${ }^{14}$

Ukuran bayi ketika lahir berhubungan dengan pertumbuhan linier anak. ${ }^{5}$ Kelahiran bayi dengan berat lahir yang rendah (BBLR) menunjukkan adanya retardasi pertumbuhan dalam uterus baik akut maupun kronis. ${ }^{5}$ Sebagian besar bayi dengan berat lahir rendah memiliki kemungkinan mengalami gangguan pertumbuhan pada masa anak-anak karena lebih rentan terhadap penyakit diare dan penyakit infeksi. ${ }^{4,15}$ Hasil penelitian menunjukkan berat badan lahir bukan merupakan faktor risiko kejadian stunting $(\mathrm{p}=1,000)$. Sebagian besar subyek baik kelompok kasus $(93,5 \%)$ maupun kontrol $(90,3 \%)$ memiliki berat lahir yang normal. Hasil ini berbeda dengan penelitian sebelumnya di Indramayu yang menunjukkan bahwa bayi stunting terbanyak pada bayi dengan berat badan lahir yang rendah. ${ }^{16} \mathrm{Hal}$ ini terjadi karena efek berat badan lahir terhadap stunting terbesar pada usia 6 bulan awal, kemudian menurun hingga usia 2 tahun. Bila pada 6 bulan awal, balita dapat melakukan kejar tumbuh maka ada kemungkinan balita dapat tumbuh dengan tinggi badan normal. ${ }^{14}$ Sedangkan subyek penelitian ini adalah balita usia 24-36 bulan sehingga berat badan lahir tidak memiliki pengaruh signifikan yang terhadap terjadinya stunting. Pertumbuhan setelah usia 6 bulan lebih dipengaruhi oleh pola asuh makan ibu yang baik dalam pemberian ASI eksklusif, MP ASI maupun perawatan kesehatan. ${ }^{14,15}$ Selain itu, data yang diambil adalah data sekunder sehingga ada kemungkinan data tidak akurat.

Penyakit infeksi juga mempunyai efek substansial terhadap pertumbuhan linier. Penyakit 
infeksi yang berhubungan dengan pertumbuhan linier adalah penyakit diare dan infeksi saluran pernafasan. ${ }^{7,17}$ Hasil analisis bivariat menunjukkan bahwa riwayat diare akut merupakan faktor risiko kejadian stunting $(\mathrm{p}=0,011)$ dimana balita yang sering mengalami diare akut berisiko 2,3 kali lebih besar tumbuh menjadi stunting, sedangkan analisis multivariat menunjukkan bahwa diare akut tidak berpengaruh sehingga pada penelitian ini diare tidak terbukti sebagai faktor risiko kejadian stunting. Hasil ini sejalan dengan penelitian di Bogor yang menunjukkan tidak terdapat perbedaan yang bermakna antara morbiditas diare antara anak stunting dan normal. ${ }^{17}$ Akan tetapi, hasil tersebut berbeda dengan penelitian di Peru yang membuktikan bahwa kejadian diare dapat menyebabkan efek jangka panjang berupa defisit pertumbuhan tinggi badan. ${ }^{7}$ Selama diare terjadi malabsorbsi zat gizi, dehidrasi dan kehilangan zat gizi. Bila kondisi tersebut tidak segera ditangani dan diimbangi asupan makan yang adekuat, maka akan timbul dehidrasi parah, malnutrisi dan gagal tumbuh. ${ }^{18}$ Tidak adanya pengaruh yang bermakna pada analisis multivariat disebabkan adanya pengaruh variabel lain yang lebih kuat, mengingat variabel yang berpengaruh dianalisis secara bersamaan sehingga kemungkinan kejadian diare dikontrol oleh variabel lain yang lebih besar pengaruhnya. Selain itu, infeksi hanya diukur dalam kurun waktu tiga bulan tanpa melihat riwayat infeksi pada tahun sebelumnya dan ada kemungkinan terjadinya bias ketika wawancara sehingga dalam penelitian ini tidak ditemukan hubungan yang signifikan. Hasil penelitian ini juga menunjukkan bahwa infeksi saluran pernafasan atas akut merupakan faktor risiko kejadian stunting yang tidak bermakna $(p=0,297 ; O R=1,73)$. Hasil ini berbeda dengan penelitian di Bogor yang mengungkapkan bahwa infeksi saluran pernafasan atas berhubungan dengan status gizi $\mathrm{BB} / \mathrm{U}$ dan TB/U. ${ }^{17}$ Hal ini dimungkinkan karena infeksi pernafasan atas merupakan infeksi yang umum terjadi dan mudah menular pada anak. Infeksi yang terjadi juga tergolong ringan dimana demam yang menyertai batuk pilek berlangsung 2-3 hari. ${ }^{19}$ Infeksi saluran pernafasan atas dapat sembuh dengan sendirinya dalam waktu yang singkat dan pada penelitian ini gejala infeksi pernafasan yang terjadi mungkin tidak mempengaruhi nafsu makan balita sehingga tidak sampai menurunkan status gizi balita. ${ }^{14,17,19}$

Kondisi kesehatan dan gizi ibu selama kehamilan dapat mempengaruhi pertumbuhan dan perkembangan janin. ${ }^{4}$ Ibu dengan status gizi rendah, mengalami anemia, atau terkena penyakit infeksi selama kehamilan meningkatkan risiko kelahiran BBLR yang meningkatkan risiko bayi tumbuh menjadi stunting. ${ }^{4,15}$ Hasil penelitian menunjukkan riwayat penyakit kehamilan merupakan faktor risiko kejadian stunting yang tidak bermakna secara statistik $(\mathrm{p}=0,562 ; \mathrm{OR}=1,4)$. Hal tersebut dimungkinkan karena kondisi kesehatan ibu selama hamil lebih berpengaruh pada proses kelahiran dan outcome bayi yang dilahirkan, sedangkan pertumbuhan bayi setelah kelahiran banyak dipengaruhi oleh faktor lingkungan seperti asupan zat gizi, pola asuh atau penyakit infeksi. ${ }^{20}$ Selain itu, dalam penelitian ini tidak dilihat waktu terjadinya penyakit dimana anak berisiko menjadi stunting bila gangguan kesehatan atau status gizi ibu yang rendah dimulai pada awal kehamilan. ${ }^{5}$ Instrumen yang digunakan juga berupa kuesioner sehingga ada kemungkinan terjadinya bias yang dapat mempengaruhi hasil penelitian. Kondisi kehamilan yang diduga berhubungan dengan kejadian stunting adalah status gizi sebelum dan selama kehamilan serta pertambahan berat badan ibu selama kehamilan dimana hal tersebut menjadi keterbatasan penelitian. $^{21}$

Tinggi badan orang tua berhubungan dengan pertumbuhan fisik anak. Ibu yang pendek merupakan salah satu faktor yang berhubungan dengan kejadian stunting. ${ }^{6,17}$ Hasil analisis bivariat dan multivariat menunjukkan bahwa tinggi badan ibu dan tinggi badan ayah merupakan faktor risiko kejadian stunting pada balita usia 24-36 bulan. Hasil ini sejalan dengan penelitian di Tangerang yang menunjukkan bahwa anak yang dilahirkan dari ibu atau ayah pendek berisiko menjadi stunting. ${ }^{22}$ Salah satu atau kedua orang tua yang pendek akibat kondisi patologi (seperti defisiensi hormon pertumbuhan) memiliki gen dalam kromosom yang membawa sifat pendek sehingga memperbesar peluang anak mewarisi gen tersebut dan tumbuh menjadi stunting. Akan tetapi, bila orang tua pendek akibat kekurangan zat gizi atau penyakit, kemungkinan anak dapat tumbuh dengan tinggi badan normal selama anak tersebut tidak terpapar faktor risiko yang lain. ${ }^{23}$

Kondisi sosial ekonomi juga dapat mempengaruhi status gizi balita. Pada penelitian ini, faktor sosial ekonomi yang dianalisis adalah pendidikan orang tua, pengetahuan ibu tentang gizi, pendapatan perkapita dan jumlah anggota dalam rumah tangga. Hasil analisis bivariat dan multivariat menunjukkan bahwa tingkat pendidikan ibu adalah faktor risiko kejadian 
stunting yang tidak bermakna sedangkan tingkat pendidikan ayah merupakan faktor risiko kejadian stunting yang bermakna. Hasil penelitian ini sejalan dengan penelitian di Bangladesh dan Tangerang yang menyatakan pendidikan ayah lebih berpengaruh terhadap kejadian stunting. ${ }^{22,24}$ Tingkat pendidikan akan memudahkan seseorang atau masyarakat untuk menyerap informasi dan mengimplementasikannya dalam perilaku dan gaya hidup sehari-hari. ${ }^{17,25}$ Pendidikan ayah yang tinggi biasanya terkait dengan pendapatan keluarga dan pola pengasuhan anak seperti penggunaan jamban tertutup, imunisasi anak, pemberian kapsul vitamin A, penggunaan garam beryodium dan pemanfaatan pelayanan kesehatan. $^{24}$ Tingkat pendidikan ibu yang tidak bermakna diduga terkait dengan status pekerjaan ibu dimana ibu yang berpendidikan tinggi biasanya memiliki pekerjaan. Hasil penelitian menunjukkan $58,1 \%$ ibu pada kelompok kasus merupakan ibu rumah tangga dan 41,9\% ibu bekerja sebagai pedagang, buruh, cleaning service, atau penjaga toko. Ibu yang bekerja menyebabkan berkurangnya waktu ibu dalam mengasuh anak sehingga perhatian terhadap pemberian makan pada anak ikut berkurang dan menyebabkan anak menderita kurang gizi, yang selanjutnya berpengaruh buruk terhadap pertumbuhan dan perkembangan anak. ${ }^{25}$

Hasil analisis bivariat juga menunjukkan pengetahuan ibu tentang gizi merupakan faktor risiko kejadian stunting yang bermakna. Akan tetapi, hasil analisis multivariat menunjukkan pengetahuan ibu tentang gizi tidak berpengaruh terhadap kejadian stunting. Pengetahuan ibu tentang gizi akan menentukan perilaku ibu dalam menyediakan makanan untuk anaknya. Ibu dengan pengetahuan gizi yang baik diharapkan dapat menyediakan makanan dengan jenis dan jumlah yang tepat agar anak dapat tumbuh dan berkembang secara optimal. ${ }^{17}$ Tidak adanya pengaruh yang bermakna pada analisis multivariat dimungkinkan karena pengetahuan ibu bukan satusatunya faktor dan bukan merupakan faktor langsung yang mempengaruhi status gizi balita. ${ }^{17}$ Terdapat faktor lain yang dapat mempengaruhi status gizi balita diantaranya pola konsumsi makan, penyakit infeksi dan pendapatan perkapita. ${ }^{17}$ Selain itu, pengetahuan dasar mengenai gizi yang cukup tanpa diikuti sikap, keterampilan dan kemauan untuk bertindak tidak dapat membawa perubahan perbaikan gizi balita. ${ }^{26}$

Pendapatan perkapita juga merupakan faktor yang turut menentukan status gizi balita. ${ }^{8}$ Hasil analisis bivariat dan multivariat menunjukkan bahwa pendapatan perkapita merupakan faktor risiko kejadian stunting pada balita usia 24 - 36 bulan. Hasil ini sejalan dengan penelitian di Maluku yang menunjukkan bahwa tingkat pendapatan yang rendah berhubungan dengan stunting. ${ }^{12}$ Kemiskinan yang berlangsung dalam waktu lama dapat mengakibatkan rumah tangga tidak mampu untuk memenuhi kebutuhan pangan dengan kuantitas dan kualitas yang baik. Penurunan kualitas konsumsi pangan rumah tangga yang dicirikan oleh keterbatasan membeli pangan sumber protein, vitamin dan mineral akn berakibat pada kekurangan gizi, baik zat gizi makro maupun mikro. ${ }^{8,26}$ Besar anggota keluarga juga turut menentukan ketersediaan pangan dalam keluarga. Jumlah anggota dalam rumah tangga yang bertambah menyebabkan pangan untuk setiap anak menjadi berkurang dan distribusi makanan tidak merata sehingga menyebabkan balita dalam keluarga tersebut menderita kurang gizi. ${ }^{8}$ Hasil penelitian menunjukkan bahwa jumlah anggota dalam rumah tangga merupakan faktor risiko kejadian stunting yang tidak bermakna $(\mathrm{OR}=1,1$; $\mathrm{p}=0,793)$. Tidak bermaknanya hasil ini dimungkinkan karena $77,4 \%$ keluarga pada kedua kelompok hanya memiliki seorang anak balita sehingga anak balita mempunyai kesempatan untuk diperhatikan lebih baik oleh orang tuanya. ${ }^{8}$

\section{KETERBATASAN PENELITIAN}

Penelitian ini menggunakan desain kasus kontrol yang bersifat retrospektif sehingga ada kemungkinan terjadi recall bias. Upaya untuk meminimalkan recall bias yang dilakukan peneliti adalah melakukan uji coba observasi dan kuesioner di lapangan. Selain itu, disarankan menggunakan instrumen lain dengan bias yang lebih kecil seperti catatan medik. Instrumen yang digunakan dalam penelitian ini adalah kuesioner yang memungkinkan terjadi interview bias sehingga responden salah dalam menafsirkan pertanyaan. Oleh karena itu, disarankan jumlah enumerator seminimal mungkin dan dilakukan pelatihan terhadap enumerator. Riwayat penyakit kronis pada balita dan ibu selama kehamilan tidak diteliti.

\section{KESIMPULAN}

Ibu yang pendek, ayah yang pendek, tingkat pendidikan ayah yang rendah dan pendapatan perkapita yang rendah merupakan faktor risiko yang paling berpengaruh terhadap kejadian stunting pada balita usia $24-36$ bulan. 


\section{DAFTAR PUSTAKA}

1. WHO. Nutrition Landscape Information System (NLIS) Country Profile Indicators: Interpretation Guide. Switzerland:WHO press; 2010.

2. Badan Penelitian dan Pengembangan Kesehatan Departemen Kesehatan RI. Laporan hasil Riset Kesehatan Dasar 2010. Jakarta; 2010.

3. Milman A, Frongillo EA, Onis MD, Hwang JY. Differential Improvement among Countries in Child Stunting Is Associated with Long-Term Development and Specific Interventions. The Journal Of Nutrition [internet]. 2005[cited 2011 October 10]. Available from: http://www.jn.org

4. Keefe CJL, Couch SC, Philipson EH. Handbook of Nutrition And Pregnancy. USA: Humana Press; 2008. p. 27 -28.

5. Kusharisupeni. Peran Status Kelahiran terhadap Stunting pada Bayi: Sebuah Studi Prospektif. Jurnal Kedokteran Trisakti. 2002; 23: 73-80

6. Zottarelli LK, Sunil TS, Rajaram S. Influence of Parental and Socioeconomic Factors on Stunting in Children Under 5 Years in Egypt. Eastern Mediterranean Health Journal [internet].2007 [cited 2012 May 5]. Available from: http://www.emro.who.int/emhj/1306

7. Checkley W, Epstein LD, Gilman RH, Cabrera L, and Black RE. Effects of Acute Diarrhea on Linear Growth in Peruvian Children. American Journal Epidemiolgy [internet].2003 [cited 2011 October 16]. Available from: http://aje.oxfordjournals.org

8. Chaudhury RH. Determinants of dietary intake and dietary adequacy for pre-school children in Bangladesh. Bangladesh Institute of Development Studies [cited 2012 March 29]. Available from: http://archive.unu.edu/

9. Dinas Kesehatan dan Kota Semarang. Laporan Pemantauan Status Gizi 2011. Semarang: 2011.

10. BPS. Penduduk Miskin Kabupaten/Kota Jawa Tengah [internet] 2010 [cited 2012 June 7]. Available From: http://www.jateng.bps.go.id.

11. Notoadmodjo S. Pengantar Pendidikan Kesehatan dan Ilmu Perilaku Kesehatan. Yogyakarta: Andi Offset. 2003

12. Ramli, Kingsley EA, Inder KI, Bowe SJ, Jacobs J, Dibley MJ. Prevalence and Risk Factors for Stunting and Severe Stunting Among UnderFives in North Maluku Province of Indonesia. BMC pediatrics [internet]. 2009 [cited 2011 October 28]. Available from: http://www.ncbi.nlm.nih.gov/

13. Gershwin M, Nestel P, Keen C. Handbook of nutrition and immunity. New Jersey: Humana Press; 2004.71-85.

14. Adair LS, Guilkey DK. Age spesific determinants of stunting in Filipino children. The Journal of Nutrition.1997;127(2).
15. Whitney E, Rolfes SR. Understanding nutrition. 11th ed. USA: Thomson Wadsworth; 2008. p. 525, 527, 550-6,

16. Kusharisupeni. Growth Faltering pada Bayi di Kabupaten Indramayu Jawa Barat. Makara Kesehatan. 2002; 6: 1-5.

17. Astari LD.Faktor-faktor yang berpengaruh terhadap kejadian stunting balita usia 6-12 bulan di Kab.Bogor [Tesis]. Bogor: Institut Pertanian Bogor. 2006

18. Dewey KG, Mayers DR. Early child growth: how do nutrition and infection interact? Maternal and child nutrition [internet] [cited 2012 March 21th]. Available from: http://onlinelibrary.wiley.com

19. Roche A, Sun S. Human growth: assesment and interpretation. Cambridge: Cambridge University Press; 2005. 75-110.

20. Medhin G, Hanlon C, Dewey M, Alem A, Tesfaye F, Worku B et al. Prevalence and predictors of undernutrition among infants aged six and twelve months in Butajira, Ethiopia: The P-MaMiE Birth Cohort. BMC Public Health 2010, 10:27.

21. Pojda J, Kelley L. Low Birthweight-Nutrition policy discussion paper no 18. Geneva : United Nation Administrative Committe on Coordination Sub-Committee on Nutrition (ACC/SCN); 2000.

22. Rahayu LS. Associated of height of parents with changes of stunting status from 6-12 months to 3-4 years[Thesis]. Yogyakarta: Universitas Gajah Mada; 2011.

23. Amigo H, Buston P, Radrigan ME. Is there arelationship between parent's short height and their children's? Social interclass epidemiologic study. Rev Med Chil 1997; Aug;125(8).

24. Semba RD, de Pee S, Sun Kai, Sari M, Akhter N, Bloem MW. Effect of parental formal education on risk of child stunting in Indonesia and Bangladesh: a cross-sectional study. Lancet 2008; 371: 322-28

25. Girma W, Genebo T. Determinants of Nutritional Status of Women and Children in Ethiopia. Calverton, Maryland, USA: ORC Macro. 2002

26. Soekirman. Ilmu gizi dan aplikasinya untuk keluarga dan masyarakat. Jakarta: Departemen Pendidikan Nasional; 2000. 